\title{
Implications of colonizing biofilms and microclimate on west stucco masks at North Acropolis, Tikal, Guatemala
}

Benjamín Otto Ortega-Morales ${ }^{1 *}$, Seiichi Nakamura², Gustavo Montejano-Zurita ${ }^{3}$, Juan Carlos Camacho-Chab, Patricia Quintana ${ }^{4}$ and Susana del Carmen De la Rosa-García ${ }^{1}$

\begin{abstract}
Introduction: The Mayan archaeological sites belong to the World cultural heritage. The porous nature of limestone and stucco (calcareous coating) along with the high humidity and temperature typical of Southern Mexico and Central America, make these monuments prone to stone biodeterioration. The Mayan masks and stelae of the North Acropolis Complex (Tikal, Guatemala) are one of the most emblematic and valuable items at this site. As a common practice to keep these items from weathering, archaeologists and restorers build palm roofs over them. A field survey undertaken in august 2006 has shown that the West Mask (WM) semi-protected under a roof was heavily colonized by biofilms and display decayed feature. The East Mask (EM) located in a vault and kept from the exterior environment appears dry and sound. The apparent correlation of biofilm coverage and substratum deterioration led us to hypothesize that biofilm coating the WM had deteriogenic activity.

Results: The purpose of this study was to characterize the biofilms colonizing WM, determine efflorescence chemistry and monitor microclimate under the palm roof in order to shed light on the ongoing deterioration phenomena. Contrasting microclimates were observed associated with WM and EM, with varying levels of relative humidity, sunlight and temperature being linked to the former. These conditions allowed the development of biofilm communities dominated by cyanobacteria only on the WM. Some of the detected taxa are recognized endolithic organisms (i.e. Gloecapsa). Fourier-transformed infrared spectroscopy showed that polysaccharides dominated the chemistry of biofilms. X-ray diffraction analyses (XRD) confirmed the presence of halite, gypsum and weddellite in efflorescences associated with the WM. Our results suggest that the joint impact of a varying microclimatic regime and the presence of biofilms promoted the deterioration.
\end{abstract}

Conclusions: The use of palm roofs as protective practice in the Mayan area should be reassessed. Although they prevent deterioration stucco masks and stelae from direct exposure to the environment, they also induce a microclimate suitable for phototrophic biofilms capable of deteriorating directly and indirectly stucco materials. Management of microclimate and biofilm control should be further investigated as additional means to conserve these valuable items.

Keywords: Biodeterioration, Biofilms, Cyanobacteria, Exopolymers, Mayan monuments, Microclimate, Salt weathering, Stucco, Water retention

\footnotetext{
* Correspondence: beortega@uacam.mx

'Departamento de Microbiología Ambiental y Biotecnología, Universidad

Autónoma de Campeche, Av. A. Melgar s/n, Campeche C.P. 24030, México

Full list of author information is available at the end of the article
} 


\section{Introduction}

Microbial communities readily colonize as biofilms both ancient and modern stone buildings in Latin America [1-3]. These communities colonize different zones of the substratum growing as epiliths on the surface or endolithic consortia within cracks and pores [4]. Globally they can be termed lithobiontic biofilms [5].

Mayan monuments provide two main types of available substrata for colonization, limestone and stucco. Stucco is a composite material made of burnt limestone, sand and plant extracts [6]. Lithobiontic biofilms comprise a range of organisms including bacteria, cyanobacteria, algae, lichens, filamentous fungi and yeasts. In the tropics, cyanobacteria are often the dominant organisms within biofilms [7].

It is now widely accepted that colonization by biofilms may lead to biodeterioration [4]. According to Scheerer and coworkers (2009) microorganisms may contribute to stone deterioration by discoloring the surfaces, trapping dirt and excreting deteriorating acid and alkaline metabolites [8]. Physical deterioration by lichens and fungal hyphae is also common $[9,10]$. Several studies have shown that phototrophs in association with heterotrophs deteriorate by growing endolithically in limestone blocks of Mayan monuments located in northern Yucatan Peninsula [2,3]. Endolithic growth is often considered a strategy to cope with stress imposed by desiccation. Under more humid conditions and when the substratum has been highly weathered, microbial growth is often overgrown by mosses providing appropriate conditions (a "proto-soil") for the germination of higher plants [11] such as in the case of exterior walls of the Jaguar Temple at Tikal, Guatemala [12]. Further deterioration may thus result by mechanical expansion of cracks and fissures by damaging plant roots, a rather common feature in the tropics. The North Acropolis is a sacred place, chosen for burial ground of the Rulers of Tikal for over 5 centuries (Figure 1).

The North Acropolis was occupied for at least 1500 years, as demonstrated by more than a dozen successive construction levels. From the beginning, the acropolis was built atop a large artificial terrace, which supported numerous buildings with ritual activities. Associated stelae face the south, portraying rulers and past events. They portray the rulers of Tikal [13]; others record transcendental events in their lives. Between 200 B.C. and 200 A.D. Maya architects across the northern Petén area designed short, broad temples with wide staircases flanked by ten-feet tall stucco masks portraying deity faces [14]. These masks used to be painted in brilliant colors including red, green, yellow, and blue; they were directly exposed to the exterior environment without any protection. Nowadays, most masks are gone due to deterioration. The remaining masks exhibit a range of conservation status. Those fully exposed to the exterior are badly deteriorated probably by karstic dissolution [12] and thermal weathering [15,16]. The WM in Structure 33D which is open to visitors is partially protected from the exterior by means of palm (guano) roof built by archaeologists and restorers (Figure 2A). Palm is a natural material displaying excellent thermal properties.

In contrast, the EM (Figure 2B) is located in a vault inside Structure 33D, connected to the exterior only by means of a narrow tunnel. It is not available for visitors. During a field survey at Tikal in august of 2006, a visual inspection showed the EM was not colonized and displayed a good state of conservation. This conservation status was confirmed by preliminary hardness measurements; when the stucco surface was punctured with a scalpel, it penetrated slightly. Conversely, the WM was almost completely covered with massive biofilms, except on the top of the mask (tuft) where biofilms were seen peeling and detaching. Underneath the biofilms, the substratum often was softened, with some loose material being detected. Small efflorescences were also observed. The apparent correlation of biofilm coverage and substratum deterioration led us to hypothesize that the WM was biodeteriorated.

The purpose of this study was to characterize the biofilms colonizing WM, determine efflorescence chemistry and monitor microclimate under the palm roof in order to provide a preliminary assessment of the ongoing deterioration phenomena.

\section{Methods}

\section{Climate data}

Minimum and maximum temperatures, precipitation and relative humidity $(\mathrm{RH})$ data were obtained for the meteorological observatory of Tikal (N 17¹3'19.758”, W $\left.89^{\circ} 37^{\prime 2} 25.03^{\prime \prime}\right)$, Guatemala. Data were obtained from Instituto Nacional de Sismología, Vulcanología, Metereología e Hidrología (INSIVUMEH), Guatemala in April $11^{\text {th }}$, 2013. Taking into account that microbial colonization of buildings may take several years [17] and according to our own extensive observations, epilithic biofilms become visually detectable on buildings after 5 years. The climatic variables were averaged from monthly data recorded for the period 2000-2006.

\section{Microclimate monitoring}

It is known that microclimate exerts a critical control over built heritage weathering and biofilm community development [18-20], Therefore, the microclimate surrounding the WM and EM was monitored. Temperature and relative humidity were recorded during a month using thermohygrometers Sato Keiryoki MFG (Aurora90 III) at four points: a) at the ground level in front of the WM, b) at $3 \mathrm{~m}$ height at the top of the WM, c) within the tunnel leading to the EM, d) the fourth 


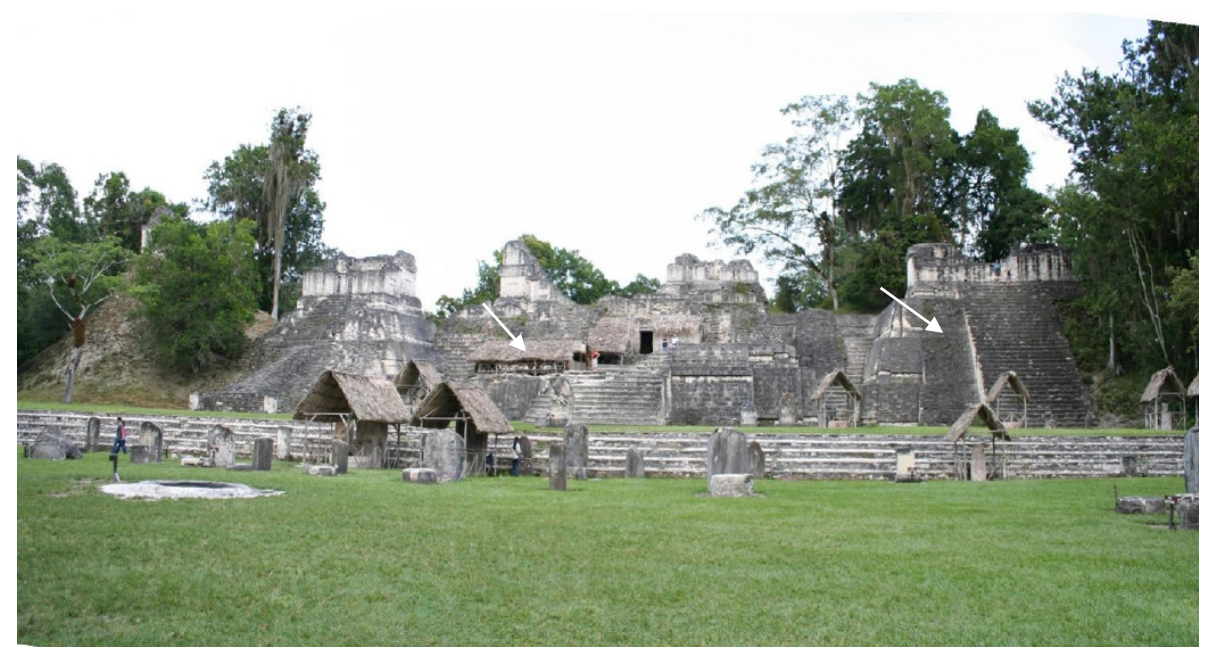

Figure 1 North Acropolis complex exhibiting microbial (black/gray) biofilms on surfaces, particularly on sloped sections (right arrow). Note that growth is scarce on vertical walls, except on run-off areas. The WM is covered by a palm roof for protection (left arrow).

thermohygrometer was placed in front of the EM. Limited access to the site allowed us to perform only single determinations of light intensity, instead of entire diurnal cycle monitoring. This variable was measured at a distance of about $2 \mathrm{~cm}$ above biofilms, using a Li-Cor 1400 Quantum/Radiometer equipped with a LI-190SA quantum sensor (Li-Cor LI-1400, Lincoln, NE).

\section{Sampling}

Guatemalan National Laws protect Mayan archaeological sites. Thus, a limited amount of biofilm material was obtained from two different points of the WM representing typical phenomenologies of Mayan monuments [18]. A fair correlation of the phenomenology of biological alterations in surfaces with the occurrence of different microorganisms has been reported [21].
Samples were drawn from two points across the stucco Mask (Figure 2A). It is noteworthy to emphasize that biofilms from upper section of the mask often appeared as peeling black thin crusts (Figure 2A, upper arrow) while biofilms from the lower section were heavier, moister and also were firmly attached to the substratum (Figure 2A, lower arrow). Samples were obtained by gentle scraping with a sterile plastic implement. They were placed into sterile Eppendorf tubes and shipped overnight to the laboratory for analysis.

\section{Biofilm analyses}

Biofilms were analyzed to determine the composition of phototrophs and to assess its chemical components. Cyanobacteria were identified according to manuals of Komárek and Anagnostidis [22,23]. Observations and
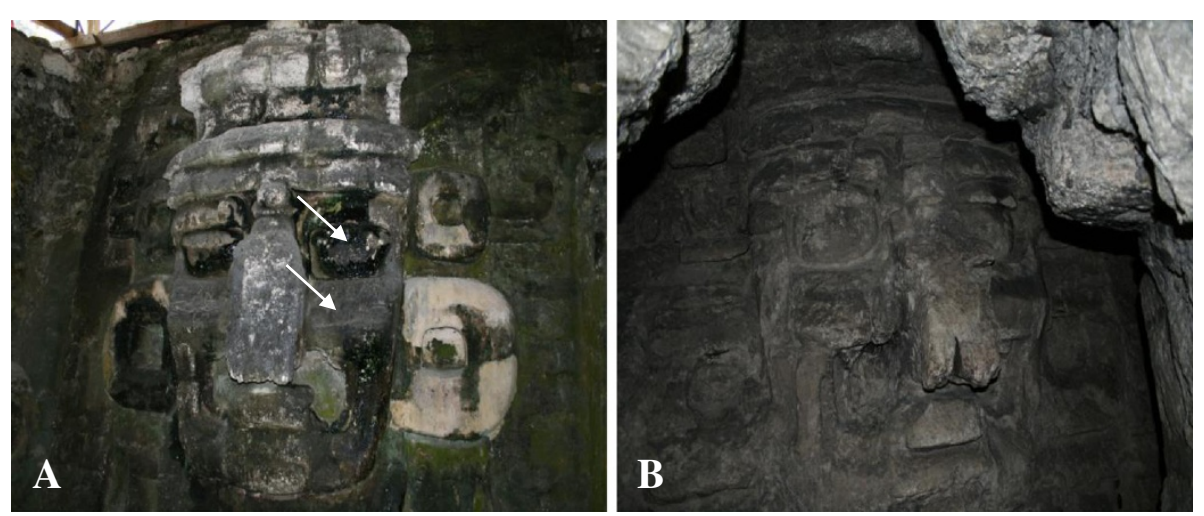

Figure 2 Masks exhibited in the North Acropolis, Tikal, Guatemala. (A) West Mask (WM) heavily colonized by phototrophic biofilms. (B) East Mask (EM) devoid of phototrophic biofilms and appearing dry and in sound condition. Note that WM (A) is covered by two main types (phenomenologies) of biofilms: dry/dark (lower arrow) and mucilaginous black (upper arrow). 
measurements were made in an Olympus BX51 microscope equipped with DIC, epifluorescence and an Olympus DP-12 digital camera. Previous studies have established the utility of Fourier Transform Infrared Spectroscopy (FT-IR) for investigation of microbial biofilms [24]. All spectra were acquired with a $4 \mathrm{~cm}^{-1}$ resolution and 100 scans using a Nicolet Magna 460 FTIR spectrometer with a deuterade triglycine sulfate (DTGS) detector in the transmission mode. Compressed tablets were prepared by mixing $2 \mathrm{mg}$ of the scrapped lyophilized biofilm with $100 \mathrm{mg}$ of $\mathrm{KBr}$. Biomass was obtained from the two types of biofilms (Figure 2A). The sample 1corresponding to biofilms covering hard substratum (lower arrow, Figure 2A) and the sample 2 to biofilms coats softened stucco (upper arrow, Figure 2A). All spectra were corrected for $\mathrm{KBr}$ background using the OMNIC software.

\section{Efflorescence analysis}

Efflorescences were seen often associated with biofilms on the WM. Efflorescence development is indicative of salt deterioration [25]. Samples were characterized by the phase composition of specimens using X-ray diffraction (XRD Siemens D-5000), with a Bragg-Brentano geometry and $\mathrm{Cu}-\mathrm{K} \alpha$ radiation $(\lambda=1.5418 \AA)$ using the following scan: step size $=0.02^{\circ}, t=5 \mathrm{~s}, 5^{\circ} \leq 2 \theta \leq 70^{\circ}$. The crystallite size, $r$, was obtained using the Scherrer equation for the peak width.

\section{Results and discussion Climate}

The conditions reported from meteorological observatory at Tikal, Guatemala for the period 2000-2006 included a maximal temperature of $33^{\circ} \mathrm{C}$ and minimal of $20^{\circ} \mathrm{C}$ with $74 \%$ relative humidity and average precipitation of $1881 \mathrm{~mm}$. Moreover, precipitation data showed a marked trend indicating a rainy season and dry season. Although there are not available data regarding the number of rainy days for the study period, as a reference we took data for period 2006-2012. On average, there were 133 rainy days per year. This could be considered the "time of wetness". Taken together, these data are in agreement with the characteristic seasonal pattern in Central America comprising the dry and rainy seasons [26]. These features are consistent with a warm wet climate (humid tropical). This type of climate is rather aggressive towards limestone, a rock that is particularly susceptible to attack by natural waters. These conditions are also optimal for microbial growth.

\section{Microclimatic regime}

A limitation of our study is that microclimatic data were recorded for a short term. It is known that long-term (multiannual) monitoring is required to assess the influence of microclimate on weathering processes and geomorphic change [19]. This short-term (one month) monitoring allowed however, to establish that short-term variations of ambient temperature and relative humidity (RH\%) occurred across a transect from the WM (semiexposed) to the East Mask (virtually unexposed) located within a vault in the lower terrace of the structure 33D of North Acropolis, Tikal Guatemala (Table 1).

In contrast, relative humidity was rather stable within the vault and the tunnel with values ranging from 90 to $94 \%$. This variable exhibited a wider range of variation at the ground level in front of the WM, reaching high values of $90 \%$ and low values of $80 \%$, thus implying that $10 \%$ of $\mathrm{RH}$ changed on a daily basis, the highest levels of $\mathrm{RH}$ being reached during the night. In contrast, relative humidity varied to a greater level at $3 \mathrm{~m}$ from the ground, around the upper section of the mask, where the lowest value reached $36 \%$ during the day (12:00 to 16:00 hrs) and then peaked at 88\% after 20:00 hrs (Table 1). Temperature mirrored the behavior exhibited by the $\mathrm{RH}$, being rather stable within the vault and tunnel, slightly increasing in front the WM at the ground level, but reaching its highest level $\left(40^{\circ} \mathrm{C}\right)$ at the top of the mask. Temperature also exhibited a cyclic behavior depending on the time of the day. On the other hand, the sunlight regime showed a marked trend, being totally absent in the vault. Low levels of incident light were recorded in the tunnel $\left(2 \mu \mathrm{E} \mathrm{m} \mathrm{m}^{-2} \mathrm{~s}^{-1}\right)$, but under the palm roof, this variable reached its highest value of the recorded measurements. This microclimatic regime is in agreement with previous studies performed in Mayan sites in the Yucatan Peninsula. We have found that the milder conditions (in terms of temperature and availability of water) in interior locations of monuments are critical for biofilm growth and that such conditions correlate with the level of extant microbial biomass $[6,18]$. Visually detectable microbial biofilms are widespread in interior locations as long as sufficient levels of incident sunlight (or artificial -lamps-) are reached. According to our experience, phototrophic microbial growth is possible in interior walls of Mayan monuments at light levels as low as $1 \mu \mathrm{E} \mathrm{m}^{-2} \mathrm{~s}^{-1}$ [27]. Below this threshold, no phototrophic growth is feasible.

\section{Characterization of microbial biofilms}

Microscopic techniques confirmed the preponderance of phototrophs, from which cyanobacteria dominated. Both coccoid and filamentous forms were observed. There was an apparent difference between the phototrophic communities at the two types of biofilms sampled. The black/grey dry biofilm was more diverse than the mucilaginous biofilm (Table 2).

The majority were cyanobacterial genera (77\%), with Gloecapsopsis, Rhabdoderma (the major biomass) and 
Table 1 August 2006 microclimate monitoring at North Acropolis, Tikal, Guatemala

\begin{tabular}{|c|c|c|c|}
\hline Site & Monthly ambient temperature range & Monthly relative humidity $\%$ & 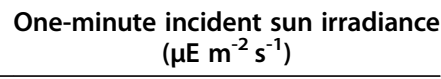 \\
\hline Upper WM under palm ceiling & $23-40^{\circ} \mathrm{C}$ & $36-88$ & 9.4 \\
\hline Lower WM under palm ceiling & $22-28^{\circ} \mathrm{C}$ & $80-90$ & $2-3$ \\
\hline Tunnel (from the WM to EM) & $24-26^{\circ} \mathrm{C}$ & $90-92$ & $1-2^{1}$ \\
\hline Vault (in front the EM) & $28^{\circ} \mathrm{C}$ & $93-94$ & u.d \\
\hline
\end{tabular}

'u.d., undetectable.

Pseudoanabaena being predominant. Rhabdoderma cells were seen embedded in a polymeric matrix, heavily covering the surfaces (Figure 3A). Of the algae, only the rhodophyte Chroothece monococa was present in both types of biofilm (Figure 3B). Our results are substantially different from the phototrophic community reported by Garcia-Miguel et al. (1995) who found that Phormidium, Plectonema, Scytonema, Chlorogloepsis, and Gloecapsa were the most representative cyanobacterial genera associated with the Pyramid of the Great Jaguar at Tikal, Guatemala.

These authors also noted that, except for Chlorella, eukaryotic algae were absent from most samples. This difference between our work and this reference study could be explained, at least in part, by the microclimate, as the community studied by Garcia de Miguel and coworkers was from exterior surfaces fully exposed to direct sunlight suffering from desiccation. However, our findings are in agreement with biofilm communities from other interior locations in Mayan sites in Yucatan [2].

FTIR-derived functional groups of biofilms are summarized in Table 3. All samples exhibited the characteristic

Table 2 Phototrophs identified in biofilms from WM in North Acropolis, Tikal

\begin{tabular}{|c|c|c|}
\hline \multirow[t]{2}{*}{ Taxa } & \multicolumn{2}{|c|}{ Type of biofilms } \\
\hline & $\begin{array}{c}\text { Dry dark green/gray } \\
\text { (sample 1) }\end{array}$ & $\begin{array}{c}\text { Mucilaginous black } \\
\text { (sample 2) }\end{array}$ \\
\hline \multicolumn{3}{|l|}{ 1.- Cyanobacteria } \\
\hline Aphanothece sp & $++^{* *}$ & - \\
\hline Chroococcus sp. & + & - \\
\hline Chlorogloea sp & +++ & - \\
\hline Gloeocapsa sp. & + & - \\
\hline Gloeocapsopsis sp. & +++ & +++ \\
\hline Pseudoanabaena sp. & +++ & +++ \\
\hline Rhabdoderma sp & ++ & +++ \\
\hline \multicolumn{3}{|l|}{ 2.- Algae } \\
\hline Chroothece monococca ${ }^{*}$ & +++ & ++ \\
\hline Unidentified chlorophyte & + & - \\
\hline
\end{tabular}

bands of polysaccharides, including the hydroxyl group bands in the $3600-3200$ and $1075-1010 \mathrm{~cm}^{-1}$ range. In addition, the amino group band at $3460-3150 \mathrm{~cm}^{-1}$ and $1650-1500 \mathrm{~cm}^{-1}$ implied the presence of proteins. Overall the FT-IR data suggested polysaccharides dominated in the samples. These data correlated with the mucilaginous aspect of biofilms and the exopolymeric material seen associated with cells, in particular those of Rhabdoderma. In line with these findings, a previous study carried out in the Mayan archaeological site of Uxmal (Mexico) showed that microbial biofilms dominated by cyanobacterial populations were heavily embedded in exopolymeric material of polysaccharidic nature [28].

\section{Implication of biofilm development and microclimate variability}

The microclimatic data recorded during this study showed that a more stable environment prevailed inside the vault. In contrast, a greater variability of microclimate was associated with the WM under the palm roof. Variation of relative humidity influences to a certain extent moisture regimes in materials. In turn, moisture in walls provides a key control on decay processes [29]. Porosity is another significant factor affecting moisture within building material. Stucco is the main building material used to build mask at Tikal. This is a rather porous material that has been shown to capture important levels of water in interior walls in the Mayan site of Uxmal, Mexico [6]. The daily fluctuation of relative humidity and temperature affects pore solution thermodynamics of building materials inducing salt weathering, a process that can generate substantial stress in rocks $[19,30]$. Thus, combination of varying microclimate and porous material (stucco) in WM seems to be related to the deterioration of this item by salt weathering. Interestingly, efflorescences were seen occurring on certain sections of the WM. Although the chemistry of these efflorescences varied, weddellite was detected in all samples. Weddellite is a weathering product of fungal metabolism [10]. In natural growth environment, subaerial fungi can use wind blown particles, rain or the substrate as sources of calcium for precipitating oxalates [31]. Oxalic acid, the principal fungal metabolite reacts with the available $\mathrm{Ca}^{2+}$ in the growth environment to 

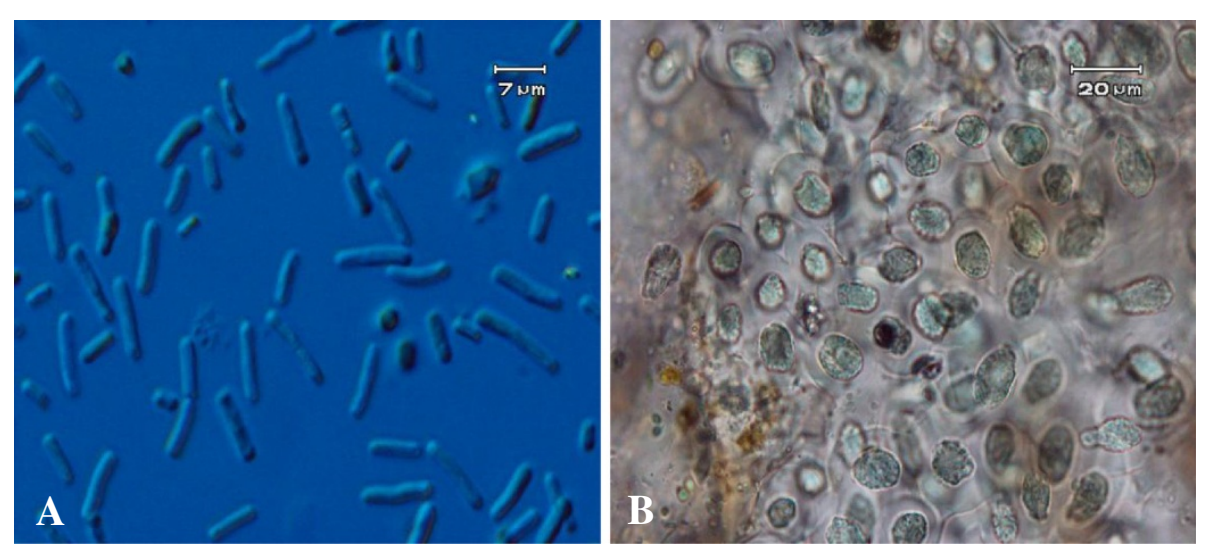

Figure 3 Cyanobacterial observed in biofilms samples. (A) Phase contrast image of Rhabdoderma cells from the mucilaginous biofilms. (B) Bright field image of the rhodophyte Chroothece.

precipitate Ca-oxalate. The formation of whewellite (calcium oxalate monohydrate) and weddellite (calcium oxalate dihydrate) depends largely on a variety of factors such as the $\mathrm{pH}$ of the growth environment, solubility of oxalates and diagenetic re-crystallization [32,33].

In addition, halite was detected in sample Tik5, whereas signals corresponding to gypsum were evidenced by X-ray diffraction analyses in sample Tik4A (Figure 4).

These findings confirm that gypsum and halite are important agents of decay in stucco [19,30]. It is important to emphasize that efflorescences were found covering certain sections of the WM but not on the EM. This is probably a synergistic effect of variation of temperature and relative humidity regimes and the presence of microbial biofilms. The presence of gypsum and halite represent an important deterioration process of monuments and probably is the result of the chemical aggression of gaseous atmospheric pollutants, mostly sulphur dioxide on calcite:

$$
\begin{aligned}
& \mathrm{CaCO}_{3}+\mathrm{H}_{2} \mathrm{SO}_{4}+2 \mathrm{H}_{2} \mathrm{O} \rightarrow \mathrm{CaSO}_{4} \cdot 2 \mathrm{H}_{2} \mathrm{O}+\mathrm{CO}_{2} \\
& \quad+\mathrm{H}_{2} \mathrm{O}
\end{aligned}
$$

Halite could also be derived from wind-blown sea sprays. Given that Tikal is located far from the coast.
This origin seems unlikely. It is therefore more possible that soluble salts containing halite and sulphate salts may be at the origin of deposited material.

Microbial exopolymeric substances (EPS) contribute significantly to the bulk of the biomass of colonizing biofilms on Mayan monuments [28]. Under a varying microclimate and due to the high hygroscopic nature of EPS, shrink-swell cycles it may be expected to occur, thus affecting mean pore size and passage of solutes [34]. This may alter salt transfer within porous networks of materials. Slow drying, by the presence of a biofilm barrier "coating" the mask surface, is a process more likely to bring dissolved salts to the surface [35]. Remarkably, we have already reported accelerated limestone deterioration by combined action of biofilms and salting in the Mayan site of Edzna [27]. Nevertheless, in order to confirm this phenomenon, experimental evidence is need to determine if biofilms in an environmental chamber mimicking the microclimate surrounding WM enhances salt-induced weathering and promotes efflorescences formation.

Furthermore, the hygroscopic nature of EPS could increase the time of wetness of stone structures, thus enhancing other abiotic deterioration process, such as dissolution. This might a very important mechanism of

\begin{tabular}{|c|c|c|}
\hline Sample 1 & Sample 2 & Functional group \\
\hline \multicolumn{2}{|c|}{ Absorption bands } & \\
\hline 3315 & 3315 & Hydroxyl group $(-\mathrm{OH})$ \\
\hline \multirow[t]{2}{*}{2928} & 2928 & Alkyl group $\left(-\mathrm{CH}_{2}-\right)$ \\
\hline & 1805 & Carboxyl group $(-\mathrm{COOH})$, aldehyde group $(-\mathrm{CHO})$ or esterfunction $(-\mathrm{COOR})$ \\
\hline 1642 & 1642 & Carbonyl group $(-\mathrm{C}=\mathrm{O}$ or $-\mathrm{CHO})$ Amide group $\left(\mathrm{NH}_{2}\right)$ \\
\hline 1450 & 1450 & Alkyl group $\left(-\mathrm{CH}_{2}-\right.$ or $\left.-\mathrm{CH}_{3}\right)$ \\
\hline 1036 & 1036 & Hydroxyl group $(-\mathrm{OH})$ \\
\hline
\end{tabular}

Table 3 FTIR spectrum analysis of functional groups of EPS present in biofilms of stucco mask 


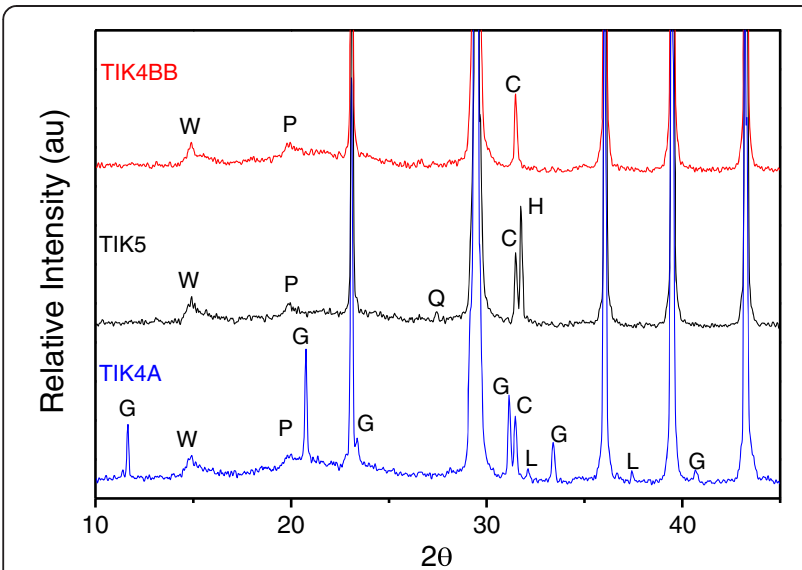

Figure $4 \mathrm{X}$-ray diffraction patterns of three samples of efflorescence material derived from WM at Tikal. Acronyms: $C$, calcite; G, gypsum, W, weddellite; Q, quartz; P, monohydrocalcite, $H=$ Halite; $L=$ Lime

deterioration on exterior surfaces as we have seen that up to 133 days per year water is available on surfaces through rain. This could explain the dry and sound (hard) condition of EM as opposed to the wet condition and softened surfaces observed on the WM. Hardness is a reliable indicator of the degree of weathering of building stone [36]. The altered microclimate condition surrounding the WM due to palm roofs exacerbated biofilms colonization that may have had additional deteriogenic effects. First, the mere presence of biofilms and their associated exopolymers, principally polysaccharides, act as glues, trapping dirt and other particulate materials, increasing the disfiguring effects of the biofilm and reducing the aesthetic appeal and value of materials. This biodeterioration is especially important when the buildings are of historic and cultural interest. Second, growth of specific taxa of known endolithic habit such as the genus Gloecapsa [2] probably contributes to the undermined state of conservation exhibited by WM.

\section{Conclusions}

The use of palm roofs is a common protective practice among archaeologists and restorers in the Mayan area of Mexico and Central America. These keep delicate structures such as stucco masks and stelae from deteriorating by thermal and dissolution processes. However, the use of this protective measure induces a varying microclimate that promotes the colonization of phototrophic biofilms, thus altering dissolved salt migration that eventually leading to deterioration. Management of microclimate by controlling relative humidity, eradicating biofilms by physical and chemical strategies and keeping them in check by using non-photosynthetic active lighting is a countermeasure that should be further investigated.
Competing interests

The authors declare that they have no competing interests.

\section{Authors' contributions}

BO-M: designed the study, sampled materials, analyzed data and wrote the paper together with JC-Ch. SN: co-designed the study, did field work and provided archaeological background and financial resources. GM-Z: identified phototrophs from biofilms. PQ and SR-G performed XRD and FTIR analyses and analyzed their data. All authors read and approved the final manuscript.

\section{Acknowledgments}

We thank JICA (Japan) and Universidad Autónoma de Campeche for providing funds for this study. We appreciate Francisco Castañeda for his valuable help during field work and data gathering.

\section{Author details}

'Departamento de Microbiología Ambiental y Biotecnología, Universidad Autónoma de Campeche, Av. A. Melgar s/n, Campeche C.P. 24030, México. ${ }^{2}$ Center for Cultural Resource Studies, Kanazawa-shi, Japan. ${ }^{3}$ Laboratorio de Ficología, Facultad de Ciencias, Universidad Nacional Autónoma de México, Av. Avenida Universidad 3000 circuito interior s/n, Coyoacán, D.F. México. ${ }^{4}$ CINVESTAV Unidad Mérida, Mérida, Yucatán C.P. 97310, México.

Received: 17 April 2013 Accepted: 25 September 2013

Published: 3 October 2013

\section{References}

1. Gaylarde PM, Gaylarde CC: A rapid method for the detection of algae and cyanobacteria on the external surfaces of buildings. In Proceedings of the Third Latin American Biodegradation and Biodeterioration Symposium. Edited by Gaylarde CC, Barbosa TC, Gabilan HN. United Kingdom: The Phycological Society; 1998:37.

2. Ortega-Morales BO, Guezennec J, Hernández-Duque G, Gaylarde C, Gaylarde P: Phototrophic biofilms on ancient Mayan buildings in Yucatan, Mexico. Curr Microbiol 2000, 40:81-85.

3. Gaylarde CC, Englert GE: Analysis of surface patina on the church of Nossa Senhora do Rosario, Ouro Preto, Brazi. In Structural Analysis of Historical Constructions. Edited by Lourenço PB, Roca P, Modena C, Agrawal S. London, UK: Taylor and Francis; 2006.

4. Golubic S, Friedmann I, Schneider J: The lithobiontic ecological niche, with special reference to microorganisms. J Sediment Res 1981, 51:475-478.

5. Gorbushina AA, Krumbein WE, Hamman CH, Panina L, Soukharjevski S, Wollenzien $\mathrm{U}$ : Role of black fungi in colour change and biodeterioration of antique marbles. Geomicrobiol J 2007, 11:205-220.

6. Ortega-Morales BO, Hernández-Duque G, Borges-Gómez L, Guezennec J: Characterization of epilithic microbial communities associated with Mayan stone monuments in Yucatan, Mexico. J Geomicrobiology 1999, 16:221-232

7. Gaylarde PM, Crispim CA, Neilan BA, Gaylarde CC: Cyanobacteria from Brazilian building walls are distant relatives of aquatic genera. OMICS a J Integrative Biol 2005, 9:30-42.

8. Scherer S, Ortega-Morales BO, Gaylarde C: Microbial deterioration of stone monuments an updated overview. Adv Appl Microbiol 2009, 66:97-139.

9. Banfield JF, Hamers R: Processes at minerals and surfaces with relevance to microorganisms and prebiotic synthesiz. In Geomicrobiology: interactions between microbes and minerals. Volume 35. Edited by Banfield JF, Nealson KH. Washington, DC: Mineralogical Society of America; 1977:81-122.

10. Gadd GM: Geomycology: biogeochemical transformations of rocks, minerals, metals and radionuclides by fungi, bioweathering and bioremediation. Mycol Res 2007, 111:3-49.

11. Falcioni G, Fedeli D, Tiano L, Calzuola I, Maancinelli L, Marsili V, Gianfranceschi G: Antioxidant activity of wheat sprouts extract in vitro: inhibition of DNA oxidative damage. J Food Sci 2002, 67:2918-2922.

12. de Miguel JM G, Sánchez-Castillo L, Ortega-Calvo JJ, Gil A, Saiz-Jimenez C: Deterioration of building materials from the Great Jaguar pyramid at Tikal, Guatemala. Build Environ 1995, 30:591-598.

13. The Tikal National Park El Petén Guatemala. http://www.tikalpark.com.

14. Coe R: Tikal, Guatemala, and emergent Maya civilization: excavations reveal evidence of early complex-living at a prime Maya Indian site. Science 1965, 147:1401-1423. 
15. Hall $K$, André MF: New insights into rock weathering from high-frequency rock temperature data: an Antartic study of weathering by termal stress. Geomorphology 2001, 41:23-35.

16. Smith BJ, Srinivasan S, Gomez-Heras M, Basheer PA, Viles HA: Near-surface temperature cycling of stone and its implications for scales of surfasse deterioration. Geomorphology 2011, 130:76-82.

17. Barberousse $H, T e l l ~ G$, Yéprémian C, Couté A: Diversity of algae and cyanobacteria growing on buildings facades in France. Algolog Stud 2006, 120:81-105

18. Ortega-Morales BO, Narvaez-Zapata JA, Schmalenberger A, Sosa-López A, Tebbe CC: Biofilms fouling ancient limestone Mayan monuments in Uxmal, Mexico - a cultivation independent analysis. Biofilms 2004, 1:79-90.

19. Viles HA: Microclimate and weathering in the central Namib Desert, Namibia. Geomorphology 2005, 67:189-209.

20. Brimblecombe $P$, Lankester $P$ : Long-term changes in climate and insect damage in historic house. Stud Conserv 2013, 58:13-22.

21. Kumar R, Kumar A: Biodeterioration of stone in tropical environments. An overview. Research in conservation: The Getty Conservation Institute Press; 1999.

22. Komárek J, Anagnostidis K: Cyanoprokaryota I. Chroococcales. Süßwasserflora von Mitteleuropa, Bd. 19/1. Germany: Gustav Fisher, Jena; 1998.

23. Komárek J, Anagnostidis K: Cyanoprokaryota II. Oscillatoriales. Süßwasserflora von Mitteleuropa, Bd. 19/2. Germany: Gustav Fisher, Jena; 2005.

24. Suci PA, Siedlecki K, Palmer RJ, White DC, Geesey G: Combined light microscopy and attenuated total reflection Fourier transform infrared spectroscopy for integration of biofilm structure, distribution, and chemistry at solid-liquid interfaces. Appl Environ Microbiol 1997, 63:4600-4603.

25. Gomez-Heras $\mathrm{M}$, Fort R: Patterns of halite ( $\mathrm{NaCl}$ ) crystallisation in building stone conditioned by laboratory heating regimes. Environ Geol 2007, 52:259-267.

26. Gómez-Cornelio S, Mendoza-Vega J, Gaylarde C, Reyes-Estebanez M, MorónRíos A, De la Rosa-García S, Ortega-Morales BO: Succession of fungi colonizing porous and compact limestone exposed to subtropical environments. Fungal Biology 2012, 116:1064-1072.

27. Ortega-Morales BO, Santiago-Garć́a JL, López-Cortés A: Biomass and taxonomic richness of epilithic cyanobacteria in a tropical intertidal rocky habitat. Bot Mar 2005, 48:116-121.

28. Ortega-Morales BO, López-Cortés A, Hernández-Duque G, Crassous $P$, Guezennec J: Extracellular polymers of microbial communities colonising limestone surfaces. In Methods in Enzymology. Volume 336. Edited by Doyle R. New York: Academic Press; 2001:331-339.

29. Sass O, Viles HA: How wet are these walls? Testing a novel technique for measuring moisture in ruined walls. J Cult Herit 2006, 7:257-263.

30. Steiger $\mathrm{M}$, Asmussen $\mathrm{S}$ : Crystallization of sodium sulfate phases in porous materials: the phase diagram $\mathrm{Na}_{2} \mathrm{SO}_{4}-\mathrm{H}_{2} \mathrm{O}$ and the generation of stress. Geochim Cosmochim Acta 2008, 72:4291-4306.

31. Braissant O, Cailleau G, Aragno M, Verrecchia E: Biologically induced mineralization in tree Milicia excels (Moraceae) its causes and consequences to the environment. Geobiology 2004, 2:59-66.

32. Gadd G: Fungal production of citric and oxalic acid: importance in metal speciation, physiology and biogeochemical processes. Advance Microbial Phisiology 1999, 41:47-92.

33. Verrechia E: Fungi and Sediments. In Microbial Sediments. Edited by Riding R, Awramik S. Berlin Heidelberg: Springer-Verlag; 2000:68-75.

34. Or D, Phutane $S$, Dechesne A: Extracellular polymeric substances affecting pore-scale hydrologic conditions for bacterial activity in unsaturated soils. Vadose Zone J 2007, 6:298-305.

35. Smith BJ, Srinivasan S, Gomez-Heras M, Muhammed PA, Viles H: Experimental studies of near-surface temperature cycling and surface wetting of stone and its implications for salt weathering. Copenhagen: SWBSS; 2008

36. Viles H, Goudie A, Grab S, Lalley J: The use of the Schmidt Hammer and Equotip for rock hardness assessment in geomorphology and heritage science: a comparative analysis. Earth Surf Process Landf 2011, 36:320-333.

doi:10.1186/2050-7445-1-32

Cite this article as: Ortega-Morales et al:: Implications of colonizing biofilms and microclimate on west stucco masks at North Acropolis, Tikal, Guatemala. Heritage Science 2013 1:32.

\section{Publish with ChemistryCentral and every scientist can read your work free of charge \\ "Open access provides opportunities to our colleagues in other parts of the globe, by allowing anyone to view the content free of charge." W. Jeffery Hurst, The Hershey Company. \\ - available free of charge to the entire scientific community \\ - peer reviewed and published immediately upon acceptance \\ - cited in PubMed and archived on PubMed Central \\ - yours - you keep the copyright \\ Submit your manuscript here: \\ http://www.chemistrycentral.com/manuscript/<smiles>c1ccccc1</smiles> \\ Chemistry Central}

